\title{
Mediating Role of Satisfaction on Relationship between Service Quality and Word of Mouth in Islamic Private Universities in Indonesia
}

\author{
Eko Handayanto \\ University of Muhammadiyah Malang \\ handayanto@umm.ac.id
}

\begin{abstract}
The research aim is to analyze the role of satisfaction as a mediator on the effect of service quality on WOM. Respondents are students who had conducted WOM in two biggest private Islamic universities owned by non-governmental organizations in Indonesia; University of Muhammadiyah Malang and University of Islam Malang. The data collected used questionnaire and are analyzed by using SEM PLS. The result shows that satisfaction has partially been mediated on the relationship between service quality and WOM.
\end{abstract}

Keywords: service quality, satisfaction, word of mouth.

\section{INTRODUCTION}

Word of Mouth or WOM is universally seen as an important factor of business success and as an informal communication among the customers that have been used as a research topic [19]. Marketing researchers and practitioners have believed that WOM is one of the marketing communication strategies that had a strong impact on marketing performance [19], and played an important role in influencing the re-purchasing decision [17] [12].

WOM can be done through online and offline (face to face) with a number of differences. First, offline WOM is the process of sharing information between two or more parties who are mutually interested, and it is voluntary, whereas the online WOM is a two-way communication that has a very wide range of opinions and experiences to share with others [13]. Second, offline WOM message's sender is closer and familiar with the receiver, so that the credibility of the sender and the message content can be easily understood by the receiver [20]. Third, offline WOM is more persuasive than the online [13]. WOM online also has its disadvantages that it may spread rapidly and expand in a short time, and has a negative impact on consumer attitudes [8]. Differences in these characteristics indicate that relative and offline WOM is more credible and persuasive than online WOM [13]. Therefore, the research is focused on offline WOM (face to face).

The diversity antecedents of WOM are caused by different objects and basic theoretical research. WOM research objects include goods and services, but services as the research object are more dominant than goods [16]. In terms of the theoretical foundation, a variety of theory was used to explain the phenomenon of WOM, such as cultural theory [17], the attribution theory [21], and the theory of satisfaction [1] [6] [9] [7].

The differentiation of research object has an implication for the diversity of variables in the model; it resulted in a research model in a partial science expansion. Consequently, the research model does not have an ability to generalize. The diversity of the basic theory suggests that WOM activity can be viewed from various aspects. The results of WOM research that have been studied were not found based on the theory of causal attribution. Therefore, it is used as the theoretical basis of this research to develop a new alternative of WOM models. Causal Attribution theory states that success is due to the internal and external factors. Attribution in marketing research is understood as an explanation of causality of events and consumer behavior [11]. In this study, Causal Attribution Theory is expected to explain the reasons for the success of WOM marketing of consumer communication, especially the success caused by internal factors.

Empirically, [1] [5] [7] indicate that customer satisfaction affects WOM. Several studies also indicate that satisfaction was not directly related to WOM (Wirtz and Chew, 2002; and Brown et al., 2005). [23] [3] [18] indicate there are no satisfaction impacts on WOM. 
Those previous researches demonstrate controversies in terms of the effect of satisfaction on WOM and need to be reanalyzed especially in the role of satisfaction related to service quality and WOM.

The objects of the research are private universities with Islamic religion background; University of Muhammadiyah Malang and University of Islam Malang. Both private universities are owned by two largest Islamic community organizations in Indonesia, namely Muhammadiyah and Nahdlatul Ulama (NU). Those universities were chosen because they have uniqueness in communication patterns. The communication pattern in NU is well known as primordial or patron-client communication where the elements of Kyai or the descendants of Kyai are in institutions, and the community becomes a central figure, whereas in Muhammadiyah, it upholds collegial communication links [22]. Differences in patterns of communication are an interesting phenomenon to be studied from the perspective of WOM.

\section{LITERATURE REVIEW}

This study is based on the theory of causal attribution as a basis for explaining the motivation of individual consumers to spread the information to others through word of mouth voluntarily. Attribution theory was first introduced by Fritz Heider in 1958. He suggests that if observing social behavior, the first thing you should do is determining in advance what causes it, ie, situational or personal factors. The assumption is that people try to understand their environment and explain the causes of internal and external to an event encountered. Attribution theory is also commonly called the external and internal causality.

There are three elements that underlie the causal properties that have cross situational generality, they are the locus, stability, and control. Weiner's attribution theory is the most influential contemporary implications on consumer behavior. Attribution theory is interpreted on the success or failure of business and consumer tendency to do the same behavior in the future. Weiner's attribution theory is more widely adopted than other attribution theories by researchers in consumer behavior. Therefore, Weiner's attribution theory was used as the theoretical basis of this research.

\section{METHOD}

This research was conducted at University of Muhammadiyah Malang (UMM) and University of Islam Malang (UNISMA) from March to April 2016. The research type is survey with students as an analysis unit. The population is registered undergraduate students at UNISMA and UMM who have ever conveyed information about college to others through WOM voluntary.

The method of determining the sample follows the assumption of the Structural Equation Modeling. To produce a good analysis of the size of the sample is determined by at least 5 times of the number of indicators that used variables. The samples technique was conducted by using a non-probability sampling, using judgment method.

Primary data were used in this study, including service quality, satisfaction, and WOM. Questionnaire method was used in the data collection. [2] steps in establishing mediation are used.

\section{RESULTS}

The path diagram of SEM is basically a diagram that connects the structural model with the measurement model. Path diagram in this study connects the latent variables of service quality, satisfaction, and WOM with their indicators as seen in Figure 1.

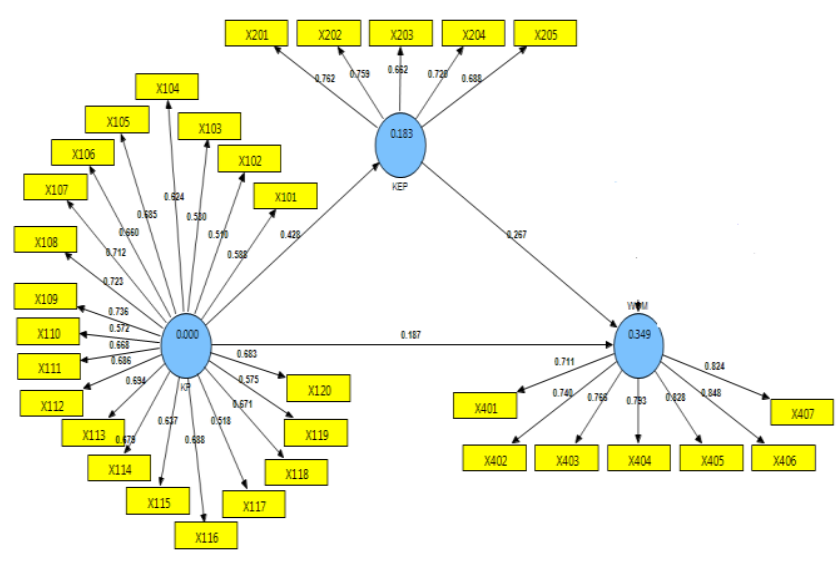

Figure 1. Diagram of Structural Model

Inner models show the meaningfulness of the relationship between the latent variables which are used to test the research hypothesis. Summary results of the inner model analysis are seen in Table 1. 


\begin{tabular}{|c|c|c|}
\hline Path & $\begin{array}{r}\text { Original } \\
\text { Sample }(\mathrm{O})\end{array}$ & $\begin{array}{cc}\mathrm{T} & \text { Statistics } \\
(|\mathrm{O} / \mathrm{STERR}|) & \end{array}$ \\
\hline $\begin{array}{c}\text { SQ -> } \\
\text { WOM } \\
\text { SQ -> }\end{array}$ & 0.1866 & 3.5021 \\
\hline $\begin{array}{l}\text { SAT } \\
\text { SAT - }\end{array}$ & 0.4281 & 4.9006 \\
\hline
\end{tabular}

Source: SmartPLS Bootstrapping, 2016.

All path coefficients are significant at alpha 0.05 because the value of $t$ statistics is greater than that of $t$ table. Those indicate that the services quality has a significant positive effect on WOM, services quality has a significant positive effect on satisfaction, and the satisfaction has a significant effect on WOM.

The analysis of mediation is involving two steps, i.e. analysis without and with mediator as seen in Figure 2a and Figure 2b.

Figure 2a. Model without Mediator

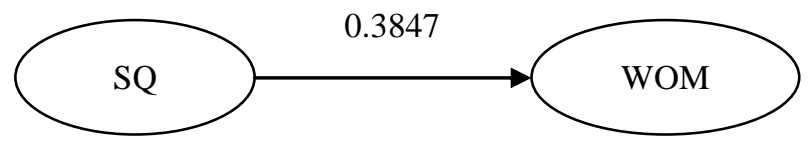

Path service quality to WOM has a positive coefficient of 0.3847 and significant at 0.05 alpha levels. This indicates that it has better service quality then higher student's WOM.

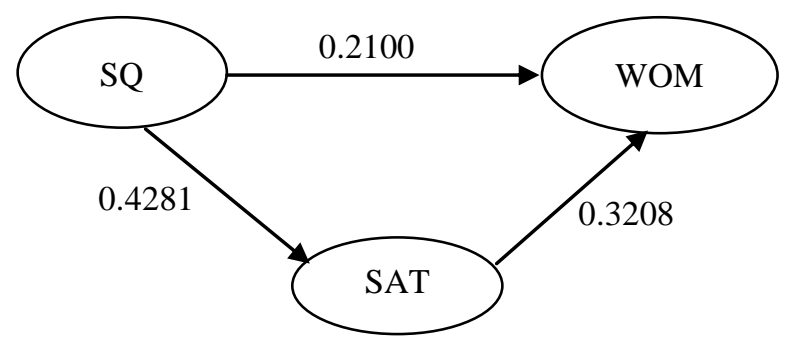

Figure 2b. Model with Mediator

After introducing satisfaction as mediator, all paths have a positive coefficient and significant. All criteria of mediation analyses criteria were completed. Based on those results, it can be concluded that satisfaction is partially mediated between service quality and WOM. It means that satisfaction has an important role as mediator in relationship between service quality and WOM.
Some reasons underlying the service quality and that have a significant and positive effect on WOM derived from most respondents' responses that service quality in Islamic private universities in Indonesia meets their expectations. Most respondents considered that Islamic private universities in Indonesia have modern equipment for lecturing, they have luxurious campus buildings, the lecturers have good performance and appearance, and the campus facilities reflect the superior service.

Most of the respondents were satisfied with the decision in choosing Islamic private universities in Indonesia and satisfied with the good service. Students are also satisfied with academic programs, as well as the students who settle in Islamic private universities in Indonesia. This indicates that their satisfaction motivate them to communicate the institutions to others through WOM voluntarily. Thus, students who feel satisfied during their study in Islamic private universities in Indonesia will be compelled to say good things and recommend and persuade other people to choose Islamic private universities in Indonesia.

The result of analysis of mediation on the relationship between service quality and WOM stated that satisfaction has partially mediated. This indicates that the management of Islamic private universities in Indonesia should always make their students satisfied with service quality. Therefore, the students will motivate to do WOM of Islamic private universities in Indonesia to other parties. This result is supported by a study conducted by [1] [7].

\section{CONCLUSION}

Better service quality will increase customer satisfaction and motivate students more to do WOM to others. This indicates that management of Islamic private universities in Indonesia should always give the best service quality to increase students' satisfaction, and it pushes student to do WOM.

The indirect effect between latent variables indicated that students' satisfaction mediates the relationship between service quality and WOM. Therefore, for future studies, it is proposed to re-analyze the model into universities with non-Islam religion background to find whether the model also works there. 


\section{REFERENCES}

[1] Babin, B. J., Lee, Y. K., Kim, E. J., and Griffin, M. Modeling Consumer Satisfaction and Word of Mouth: Restaurant Patronage in Korea, Journal of Services Marketing. Vol. 19 No. 3, pp. 133-139. 2005.

[2] Baron, R. M. and Kenny, D. A. The ModeratorMediator Variable Distinction in Social Psychological Research: Conceptual, Strategic, and Statistical Considerations, Journal of Personality and Social Psychology. 51(6): 1173-1182. 1986.

[3] Brown, R. M. and Mazzarol, T. W. The Importance of Institutional Image to Student Satisfaction and Loyalty Within Higher Education, Higher Education. Vol. 58, pp. 81-95. 2009.

[4] Brown, T. J., Barry, T. E., Dacin, P. A., and Gunst, R. F. Spreading the Word: Investigating Antecedents of Consumers' Positive Word-of-Mouth Intentions and Behaviors in Retailing Context, Academy of Marketing Science. Vol. 33 No. 2, pp. 123-138. 2005.

[5] Bruce, G. and Edgington, R. Factors Influencing Word-of-Mouth Recommendations by MBA Students: An Examination of School Quality, Educational Outcomes, and Value of the MBA, Journal of Marketing for Higher Education. Vol. 18 No. 1, pp.70-101. 2008.

[6] Casalo, L. V., Flavian, C., and Guinaliu, M. The Role of Satisfaction and Website Usability in Developing Customer Loyalty and Positive Word of Mouth in the E-banking Service, The International Journal of Bank Marketing. Vol. 26 No. 6, pp. 399-417. 2008.

[7] Chaniotakis, I. E. and Lymperopoulos, C. Service Quality Effect on Satisfaction dan Word of Mouth in the Health Care Industry, Journal of Managing Service Quality. Vol. 19 No. 2, pp. 229-242. 2009.

[8] Chevalier, J. A., and Mayzlin, D. The Effect of Word of Mouth on Sales: Online Book Reviews. Journal of Marketing Research. Vol.48 (August), pp. 345-354. 2006.

[9] De Matos, C. A., and Rossi, C. A. C. Word-of-Mouth Communications in Marketing: A Meta-Analytic Review of the Antecedents and Moderators, Journal of the Academic Marketing Science. Vol. 36, pp. 578-596. 2008.

[10] Dellarocas, C. The Digitization of Word of Mouth: Promise and Challenges of Online Feedback Mechanisms, Management Science. Vol. 49 No. 10, pp. 1407-1424. 2003.

[11] Folkes, V.S. Recent Attribution Research in Consumer Behavior: A Review and New Directions, The Journal of Consumer Research. Vol. 14 No. 4, pp. 548-565. 1988.

[12] Gremler, D. D., Gwinner, K. P., and Brown, S. W. Generating Positive Word-of-Mouth Communication Through Customer-Employee Relationships, International Journal of Service Industry Management. Vol. 12 No. 1, pp. 44-59. 2001.

[13] Herr, P. M. Kardess, F. R., and Kim, J. Effects of Word of Mouth and Product-Attribute Information on Persuasion: An AccessibilityDiagnostic Perspective, Journal of Consumer Research. Vol. 17, pp. 454-462. 1991.

[14] Laczniak, R. N., De Carlo, T. E., and Ramaswami S. N. (2001). Consumers' Responses to Negative Word-of-Mouth Communication: An Attribution Theory Perspective, Journal of Consumer Psychology. Vol. 11 No. 1, pp. 57-73.

[15] Li, S. C. (2013). Exploring the Relationships among Service Quality, Customer Loyalty and Word-Of-Mouth for Private Higher Education in Taiwan, Asia Pacific Management Review. Vol 18 No. 4, pp. 375-389.

[16] Mangold, W. G., Miller, F. and Brockway, G.R. Word-of-mouth communication in the service marketplace, Journal of Services Marketing. Vol. 13, No. 1, pp. 73-89. 1999.

[17] Money, R. B., Gilly, M. C., and Graham, J. L. Exploration of National Culture and Word-ofMouth Behavior in the Purchase of Industrial Service, The Journal of Marketing. Vol. 62 No. 4, pp.76-87. 1998. 
[18] Naik, J. R. K., Anand, B., and Bashir, I. Healthcare Service Quality and Word of Mouth: Key Drivers to Achieve Patient Satisfaction, Pacific Business Review International. Vol. 5, No. 12, pp. 39-44. 2013.

[19] Oetting, M. and Jacob, F. Empowered Involvement and Word of Mouth: An Agenda for Academic Inquiry, ESCP-EAP Working Paper. Vol. 28, pp. 1-28. 2007.

[20] Steffes, E. M., and Burgee, L. E. Social Ties and Online Word of Mouth, Internet Research. Vol. 19 No. 1, pp. 42-59. 2009.
[21] Swanson, S. R., and Kelley, S. W. Service Recovery Attributions and Word of Mouth Intentions, European Journal of Marketing. Vol. 35 No. 1/2, pp. 194-211. 2001.

[22] Tafsir. Simpang Jalan Muhammadiyah, MAARIF. Vol. 4 No. 2, pp. 20-44. 2009.

[23] Wirtz, J., and Chew, P. The Effect of Incentives, Deal Proneness, Satisfaction and Tie Strength on Word-of-Mouth Behaviour, International Journal of Service Industry Management. Vol. 13 No. 2, pp. 141-162. 2002. 